DOI: $10.30680 /$ ECO0131-7652-2018-3-155-180.

\title{
Реформы
}

\section{в электроэнергетике России в контексте развития энергетического права}

н.С. Симонов, доктор исторических наук, ведущий инженер Федеральной сетевой компании (ПАО «ФСК ЕЭС»), Москва

Предметом исследования является генезис доктрины электроснабжения как один из источников энергетического права. Доказывается, что отношение общества к вещной форме электроэнергии и энергетических услуг определяется конкретно-историческими условиями, и, главным образом, технологиями генерации и передачи электроэнергии. На обширном историческом материале с использованием методов сравнительного анализа прослеживается процесс цивилистического понимания правового режима электроснабжения в индустриально развитых странах, Российской империи, СССР и современной России. Делается вывод о том, что современные технологии способствуют либерализации электроэнергетики и созданию рыночной конкуренции между поставщиками электроэнергии.

Ключевые слова: электроэнергетика, электроснабжение, энергетическое право, естественная монополия, рынок электроэнергии

«Удивление, близкое к шоку - возникает у отдельных юристов, когда речь заходит об энергии как предмете правового регулирования. Тем не менее отношения, связанные с энергией...праву не безразличны».

[Лахно П.Г., 2013]

В части определения энергетического права как отдельной правовой отрасли у правоведов до сих пор нет единого мнения [Попондопуло, 2008. С. 207; Яковлев, Лахно, 2011. С. 62]. Но большинство все же признает его существование с определенными оговорками.

В данной статье попытаемся проанализировать объективные (производственные и технологические) причины, по которым на рубеже XX-XXI веков в России, как и во всем цивилизованном мире, произошло «отрицание отрицания» концепции меновой стоимости электроэнергии и энергетических услуг и хозяйственного механизма их отчуждения на рынке несовершенной конкуренции. 


\section{Эволюция представлений \\ о меновой стоимости электроэнергии \\ и энергетических услуг}

\section{В Российской империи}

В 1880-1890-е годы, на заре «эры электричества», электроснабжение в Российской империи в основном осуществлялось посредством частных блок-станций и являлось предметом технического регулирования в виде обязательных правил и норм по уходу и работе «с источниками электричества, электродвигателями и другими электрическими установками».

Юридические отношения между производителями (продавцами) и потребителями (покупателями) электроэнергии возникли после начала работы электростанций общественного пользования ${ }^{1}$.

Вначале эти отношения регулировались в духе ст. 1737 «Законов гражданских Российской Империи», то есть как «подряд». Последний же подразумевал, что «одна из вступающих в оный \{договор\} сторон принимает на себя обязательства исполнить своим иждивением предприятие или поставить известного рода вещи, а другая, в пользу коей сие производится, учинить за то денежный платеж».

В качестве аргумента, что электроэнергия не товар, говорило то, что товар должен характеризоваться такой особенностью, как возможность его хранения на складе Электроэнергия такой особенности, как известно, не имеет. Весь объем электроэнергии, приобретенной покупателем, сразу же им используется.

Еще одна особенность, отличающая электроэнергию от любого другого товара, - это использование для транспортировки электроэнергии самой электроэнергии. Это значит, что продавец электроэнергии не осуществляет никаких дополнительных действий для передачи ее потребителям. Ее получение фиксируется не товарно-транспортной накладной, как это положено при доставке товара, а электрофизическими средствами учета - счетчиками, установленными непосредственно у потребителя.

Выделение транспорта электроэнергии в обособленный технологический комплекс и вид предпринимательской деятельности стало возможно не ранее, чем появились протяженные высоковольтные воздушные и кабельные линии электропередачи с повышающими и понижающими подстанциями и комплектными распределительными устройствами. Произошло это в 1898-1909 гг., когда в США и Германии были построены первые районные электростанции. Тогда же услуга по передаче электричества от производителя к потребителю стала рассчитываться отдельным тарифом (в зависимости от объема присоединенной мощности и нормативных сетевых потерь).

Взаимоотношения потребителя и производителя (поставщика) электроэнергии протекают в четырех последовательных процессах: подключение, подача электроэнергии в дом/

${ }^{1}$ В 1896 г. в Российской империи насчитывалось 35 электростанций общественного пользования, отпускающих электроэнергию частным абонентам для целей освещения и моторного движения. Первые электростанции данного типа возникли в 1886-1888 гг. в С.-Петербурге и в Москве - на 4 года позже первой в мире центральной электростанции в Нью-Йорке, построенной по проекту Т. А. Эдисона. квартиру или цех/предприятие, учет поданной электроэнергии и оплата за потребленную электроэнергию.

Цикл повторяется до тех пор, пока потребитель исправно платит за потребленную электроэнергию, но, как только он прекращает платить, цикл прерывается, и поставщик, угрожая потребителю отключением от сети, какое-то время терпеливо ждет поступление платежа

Так как законы Российской империи не возбраняли приводить угрозу отключения потребителя от сети в исполнение и искать с неплательщика уплаты денег судом, неоплаченная электроэнергия уже подходила под категорию товара, имеющего потребительскую и меновую ценность. Истец, во всяком случае, должен был доказать в суде, что ответчик нанес ему не просто материальный ущерб, а материальный ущерб в определенном количестве, причем, не ниже себестоимости производства неоплаченного продукта (товара) [Розин, 1899. С. 91]

Решением от 7 мая 1902 г. Правительствующий сенат указал, что «электричество обладает всеми признаками имущества в смысле закона», то есть отпущенную потребителю электроэнергию (в соответствии с условиями Договора электроснабжения) предлагалось рассматривать в качестве «движимого имущества».

Представленным 19 декабря 1916 г. на одобрение Государственной Думы законопроектом «Об установлении налога на электроэнергию» Министерство финансов намеревалось пополнить бюджет на 17,6 млн руб. Предлагалось взимать с потребителей электроэнергии как за подакцизный товар по 1 коп./кВт.ч за уличное и по 4 коп./КВт.ч - за комнатное освещение. По 5 коп./кВт.ч облагалось налогом производственное энергопотребление. Однако ввести данный налог так и не удалось.

\section{В Советской России}

Энергетическое право первых лет Советской власти рассматривало электроснабжение как государственную производственную и торговую монополию. С государственных абонентов плата за потребленную электроэнергию национализированных электростанций фактически не взималась. Все расчеты за полезно-отпущенные киловатты осуществлялись путем перераспределения бюджетных средств с одной балансовой статьи на другую.

В 1920 г., когда советские денежные знаки совсем обесценились, плата перестала взиматься и с негосударственных абонентов - электроэнергия потеряла стоимостную оценку. При СНК была создана Чрезвычайная комиссия по электроснабжению и издан за подписью В.И. Ленина декрет (15 ноября 1920 г.) «О мерах к сокращению пользования электрической энергией и электрическим освещением».

С переходом в 1921 г. к новой экономической политике (нэп) электроснабжение перестает быть государственной монополией. Допускается существование электроснабжающих предприятий различных форм собственности: государственной, акционерной и кооперативной. Государственные электроснабжающие предприятия объединяются в тресты и переводятся на хозяйственный расчет. 
Восстанавливается плата за присоединение к сетям и вводится «классовый тариф», - с условием понижения оплаты электроэнергии для рабочих и госслужащих и повышения ее для «нэпманов».

В энергетическом праве 1922-1927 гг. договор электроснабжения трактуется как «договор купли-продажи» или как «договор последовательной поставки»: одна сторона передает другой за плату определенный товар (энергию), и каждая несет ответственность за точное и своевременное исполнение контракта.

Гражданский кодекс РСФСР (1922 г.) закрепляет правило усиленной защиты обязательств, возникающих из договоров купли-продажи. Устанавливается принцип принуждения должника к реальному исполнению обязательства, в отличие от обычного возмещения ущерба.

После «сворачивания» нэпа отношение к электроэнергии как к товару сменяется отношением к ней как к физической субстанции, плата за которую в результате полной и окончательной победы социализма должна исчезнуть вообще ${ }^{2}$.

В годы 1-й пятилетки основное назначение энергетической отрасли состояло «в надежном, бесперебойном электроснабжении потребителей в запланированных объемах и независимо от их платежеспособности» ${ }^{3}$. Для достижения этой цели весь процесс производства, передачи и потребления электроэнергии в пределах каждой районной энергосистемы жестко регламентировался приказами и инструкциями Главэнерго.

Нагрузка регулировалась методом прямого управления по требованию правительственных органов, районных энергосистем и энергокомбинатов. Баланс экономических интересов производителей и потребителей электроэнергии сводился на уровне государственных планов снижения себестоимости. Величина тарифа на полезно-отпущенную электроэнергию по этой причине приобретала искусственный характер.

Подобное отношение к электроэнергии не могло не привести к сверхрасточительному ее потреблению и к перманентному энергодефициту. 16 августа 1931 г., в связи с катастрофическим падением

${ }^{2}$ Общая экономическая записка \{Для служебного пользования\}.- М.: ВЭО ВСНХ CCCP,1931. C. 15.

Положение о взаимоотношениях электрических станций, подстанций и распределительных сетей с потребителями электрической энергии, утв. Постановлением СНК СССР от 27 декабря 1929 г. // С3 СССР.- 1930.- № 2.- Ст. 12. платежной дисциплины, вышло Постановление СНК СССР № 702 «О сроках оплаты счетов за электрическую и тепловую энергию».

Согласно документу, в случае неоплаты счетов за электрическую и тепловую энергию в течение пяти дней сверх установленных правилами или договорами сроков, энергосистемам и электростанциям предоставлялось право прекращать подачу энергии неисправным потребителям (с предварительным их уведомлением), за исключением учреждений и предприятий, условия работы которых не допускают даже временного выключения (казармы, больницы, телеграф, телефон, радиостанции и т.п.).

10 декабря 1934 г. СНК СССР принял «Положение о взаимоотношениях электрических станций и энергетических систем с потребителями электрической и тепловой энергии». Для советского энергетического права документ имеет эпохальное значение, поскольку в нем в завуалированной форме признается порочность бесхозяйственных (или бессубъектных) методов ценообразования. Впервые со времен нэп в документе говорится о том, что энергоснабжающие предприятия должны получать прибыль. Размер прибыли предлагается устанавливать народнохозяйственным планом на каждый год и учитывать при определении тарифных ставок.

Тарифные ставки на энергию устанавливались дифференцированно, в зависимости от особенностей потребления, времени, количества потребляемой энергии, коэффициента мощности и т.п. Для промышленных потребителей устанавливался «двухставочный тариф» с разделением абонентской платы на обусловленную договором мощность и за полезно-отпущенные киловатт-часы электроэнергии. Это было прямым заимствованием из американского энергетического права ${ }^{4}$.

${ }^{4}$ В 1931 г. американский экономист Джеймс Бонбрайт (James C. Bon-bright) выдвинул идею о том, что помимо собственно электроэнергии следует оплачивать также способность ее производить (т.е. мощность). В предложенной им схеме баланса интересов производителей и потребителей электроэнергии все не зависящие от объема производства электроэнергии затраты энергокомпаний должны оплачиваться потребителями безотносительно к величине потребления.

Посредством «двухставочного тарифа» потребители получали возможность заранее заказывать (абонировать) необходимый объем мощности, а энергокомпании - максимально точно рассчитать свои условно-постоянные издержки (на закупку топлива, амортизацию, оплату труда, социальные отчисления и т.д.).

С гражданско-правовой точки зрения, платежи за мощность - это составная част договора купли-продажи электроэнергии (или договора электроснабжения). 
Постановлением СНК от 10 декабря 1934 г. предусматривалась «ответственность электростанций за перерыв в подаче электрической энергии в размере двукратной стоимости недоотпущенной энергии в случае перерывов, вызванных недопоставкой топлива, и восьмикратной стоимости недоотпущенной энергии - во всех остальных случаях $\rangle^{5}$. На практике данная мера получила ограниченное применение, а в годы Великой Отечественной войны вообще не применялась: оперативно-диспетчерские управления энергосистем имели полное право «гасить» предприятия, организации и учреждения в случае превышения ими установленных лимитов энергопотребления.

\section{В зрелом СССР}

Энергетическое право периода «развитого социализма» с производственной и технологической точки зрения являлось порождением централизованного энергоснабжения, которое осуществляла Единая энергосистема страны (ЕЭС СССР). Это крупнейшее в мире энергообъединение простиралось на территории семи часовых поясов, охватывая более 700 электростанций Минэнерго СССР общей мощностью свыше 210 млн кВт. Все редакции «Правил пользования электрической энергией», которые были приняты в послевоенный период, а также Основы гражданского законодательства СССР и союзных республик не содержали никаких упоминаний о передаче права собственности на электроэнергию как товар. Сами отношения энергоснабжающей организации и потребителя в договорах энергоснабжения трактовались как абонентские и строились по модели оказания услуг.

К 1965 г. по сравнению с 1955 г. доля выработки энергии на электростанциях, не входящих в состав районных энергосистем, в общем объеме производства электроэнергии снизилась более чем в два раза. Большое количество мелких и неэкономичных установок было ликвидировано или законсервировано. Это давало возможность значительно снизить себестоимость электроэнергии, и на протяжении нескольких десятилетий она являлась относительно самым дешевым продуктом в СССР. Например, с 1970-го по 1980 г. тарифы на электроэнергию для

\footnotetext{
${ }^{5}$ Библиотека нормативно-правовых актов Союза Советских Социалистических Республик. Интернет-портал: www.libusr.ru
}

населения составляли 4 коп./кВт·ч при потреблении средней семьей из трех человек 90-100 кВт·ч в месяц.

С одной стороны, кажется, что дешевая электроэнергия благо. С другой - именно ее низкая стоимость не позволяла внедрять эффективные энергосберегающие технологии и снижать непомерно высокую энергоемкость общественного производства.

О том, что на самом деле в экономическом смысле скрывалось за «дешевой электроэнергией», утратившей свойства товара, достаточно красноречиво свидетельствует существующий и поныне механизм «перекрестного субсидирования»:

- субсидирование производства электрической энергии за счет тепловой энергии на ТЭЦ;

• субсидирование потребителей электрической энергии за счет потребителей тепла от ТЭЦ;

• субсидирование мощности (надежности) электроснабжения за счет платы за энергию;

- субсидирование мощности, резерва мощности теплоснабжения за счет платы за энергию;

• субсидирование населения по принципу «всем за счет всех»;

- субсидирование дальних потребителей за счет ближних;

- субсидирование по времени внесения затрат;

- субсидирование новых технологий в энергетике.

\section{В наши дни}

Энергетическое право постсоветского периода решительно возвращает электроэнергии и энергетическим услугам форму товара как объекта имущественных отношений. В 1995 г. вступили в силу Положения о договоре энергоснабжения, включенные в параграф 6 гл. 30 Гражданского кодекса РФ «Купля-продажа». Предметом данного договора (в узком понимании) согласно п. 1 ст. 454 ГК РФ называется вещь (товар), и предлагается считать, что предмет договора энергоснабжения (энергия) также обладает товарной характеристикой.

В ст. 3 ФЗ № 35 от 26.03.2003 «Об электроэнергетике» указывается на то, что электрическая энергия (мощность) относится к «товарам», производимым на объектах по производству электрической энергии, передаваемым через объекты электросетевого хозяйства посредством оказания услуг по передаче электрической энергии на энергопринимающие устройства.

6 ЭКО. - 2018. - № 3 


\section{Электроснабжение}

\section{как естественная монополия}

В то время как Советский Союз боролся за создание материально-технической базы социалистического общества на основе всеобщей электрификации, в мировой электроэнергетике происходили весьма противоречивые процессы, связанные с превращением электроснабжения в разновидность «естественной монополии» и введением в США и в других индустриально развитых странах ее государственного регулирования.

Научное определение понятия естественной монополии (англ. the great public utilities) сложилось не просто и не сразу. Автором термина считается британский философ, экономист и политический деятель Дж. Ст. Милль (1806-1873). Под естественной монополией он подразумевал «предприятие подлинно общественного значения, способное с выгодой осуществлять свои функции лишь в таких крупных масштабах, что свобода конкуренции при этом становится почти иллюзорной» [Милль, 1980. С. 302].

В XIX в. первой естественной монополией было признано почтовое дело, а после изобретения телеграфа - передача электромагнитных сигналов по телеграфным линиям. В 1870-е годы, в период интенсивного развития железнодорожного транспорта, практически было доказано, что экономическая эффективность железнодорожной компании напрямую зависит от ее размеров. Крупное транспортное предприятие с гораздо меньшими издержками переживает кризис грузоперевозок, ему доступнее банковский кредит, и оно имеет возможность своевременно обновлять парк локомотивов, вагонов и прочих технических компонентов железнодорожного хозяйства.

Таким образом, признавалось, что естественная монополия существует, когда экономия от масштаба позволяет одному предприятию удовлетворить весь рыночный спрос без (до) того, чтобы (как) отдача от масштаба стала снижаться [Ramsey, 1927].

Признание электроснабжения естественной монополией произошло в период, когда энергетические предприятия стали превращаться в вертикально интегрированные компании (холдинги). К этому их подталкивала сама технология производства электроэнергии в чувствительном для национального или регионального рынка объеме [Фомичева, 2013].

\section{Технологический скачок}

Реальной движущей силой процесса концентрации производства и распределения электроэнергии являлось непрерывное совершенствование энергетического оборудования, которое развивалось в пользу крупных агрегатов гидросилового и паросилового электрохозяйства.

Первые образцы горизонтальных осевых гидротурбин появились в конце 1840-х годов. Это были турбины Жонваля мощностью около 140 л.с. После 1891 г., когда стала возможной передача энергии трехфазным током, мощности турбин Жонваля стремительно возросли и приблизились в 1900 г. к 1200 кВт. Единичная мощность радиально-осевой турбины системы Френсиса выросла с 8 тыс. кВт в 1903 г. до 20 тыс. кВт в 1913-м.

В конце 1920-х происходит скачок в укрупнении единичной мощности агрегатов тепловых электростанций: мощность паровых турбин в одном агрегате увеличивается до 150-200 тыс. кВт [Гартман, 1927]. В 1930 г. в Германии 246 крупных электростанций произвели 21,2 млрд кВт·ч электроэнергии $(73,4 \%$ общего объема). Коэффициент централизации (производства электроэнергии на станциях общественного пользования) достиг 53,5\%. Наибольшая мощность отдельной станции доходила до 440 и 550 тыс. кВт. В США коэффициент централизации был еще выше - 77\%. Наибольшая мощность отдельной станции доходила до 1 млн кВт ${ }^{6}$.

В Японии пять крупных электроснабжающих обществ контролировали в 1920-е годы две трети мощности всех тепловых и гидроэлектрических станций страны. При этом между ними действовало картельное соглашение о перетоках электроэнергии по межсистемным линиям электропередачи и о взаимной поддержке резервами.

Укрупнение единичной мощности генерации и повышение напряжения линий электропередачи сопровождались снижением удельных расходов топлива. По этой причине тарифы на электроэнергию оставались стабильными, а относительно цен на большинство других потребительских товаров даже снижались. Это создавало условия для обеспечения электроэнергией все большего

\footnotetext{
6 Передовая. Электрификация СССР на грани второй пятилетки//Электричество 1933.№ 2. C.3.
} 
круга потребителей и расширения сфер ее промышленного и бытового применения.

\section{От рынка к госрегулированию}

Изъятие энергетической отрасли из сферы действия рынка в США началось в 1907 г., когда Национальная ассоциация электроосвещения и Национальная гражданская федерация вынесли постановление о государственном регулировании коммунальных компаний. В 1911 г. Конгресс США принял Закон о коммунальных предприятиях, которым ограничил права электроэнергических, газовых и водоснабжающих компаний по изменению тарифов и других параметров корпоративной политики.

Закон установил стандартные технические характеристики электрического тока, ограничил свободу слияний и поглощений для компаний электроснабжения, определил набор требований к договорам географического франчайзинга. Этим же законом были установлены границы между географическими районами, в которых работают электроэнергетические компании, и был введен запрет на «вторжение... компаний, оперирующих в другом регионе, в регион, где уже действует компания данного региона» [Leonard, 1988].

Организации, наделенные монопольным правом энергоснабжения, не могли отказать находящемуся на ее территории потребителю в поставке электроэнергии в том количестве, в котором потребитель нуждается, если последний согласен платить по установленному тарифу.

В Англии большинство электростанций общественного пользования были муниципальными. В 1927 г. при правительстве создается Центральный совет по электрификации и вводится государственная монополия оптовой продажи электроэнергии. Правительство возлагает на себя обязанности по строительству национальной электрической сети, координации передачи электроэнергии и установлению единых технологических стандартов.

Во Франции все вопросы, касающиеся развития и эксплуатации электрохозяйства, - намечаемые законодательные и административные мероприятия, строительство и расширение станций и сетей, тарификация и так далее, - рассматривались и согласовывались в специальном правительственном органе Высшем совете по электрификации [Михайлов, 1936. С. 40].

В Японии в 1920-е годы все гидроресурсы были объявлены государственной собственностью. Право на их использование давалось электроснабжающим коммерческим обществам при условии подчинения контролю государственного электробюро, которое не только утверждало проекты на начало постройки ГЭС, но и проводило испытания механизмов изготовленной установки перед тем, как выдать разрешение на ее эксплуатацию [КукельКраевский, 1930].

В Германии в конце 1935 г. принимается «Закон об энергетике», главной задачей которого является создание «единого» направления работы всех субъектов энергетического хозяйства в виде 12 тыс. электроснабжающих предприятий. Произошло своеобразное разделение пространства электроснабжения по принципу «сетевой монополии». Между фирмами и муниципальными образованиями, по территории которых прокладывались ЛЭП, заключались концессионные соглашения, а между фирмами, интересы которых сталкивались, - демаркационные.

В 1939 г. вся страна делится на 14 энергетических районов, и в каждом создается служба районного диспетчера с диспетчерскими пунктами (около 170), оснащенными всеми необходимыми приборами контроля и коротковолновыми радиостанциями для приема и передачи данных. Перетоками электроэнергии из одного энергетического района в другой руководило Главное диспетчерское управление в Берлине, которое контролировало энергосистемы не только Германии, но и Австрии, Эльзаса, Западной Польши и Судетской области

В 1947 г. лейбористское правительство Великобритании создало Центральную дирекцию по производству электроэнергии, которой были переданы в управление все электростанции и вся высоковольтная сеть. Названная организация, просуществовавшая до 1989 г., продавала электроэнергию 12 региональным распределительным компаниям по оптовому тарифу, который утверждался правительством, а те перепродавали ее конечным потребителям.

Материалы по электроснабжению Германии в предвоенный и военный периодь Берлин, 1945.Т. 1.С. 10-11. 
В советской экономике естественные монополии как специфический предмет государственно-правового регулирования не выделялись, хотя они, конечно же, там имелись. Такой надобности не возникало потому, что монополиями в своем роде являлись все отрасли народного хозяйства.

Одно из существенных отличий социалистических естественных монополий от капиталистических заключалось в том, что капиталистические монополии возникли «снизу» в результате конкурентной борьбы. Социалистические насаждались «сверху» и действовали в тепличных условиях. В монополисты при капитализме прорывались лидеры, которые использовали самые передовые технологии и имели значительный научно-технический и производственный потенциал. При социализме монополии могли существовать и на отсталой технологической базе.

\section{От естественной монополии - \\ к конкурентному рынку}

Время господства в мировой электроэнергетике жестких пулов - объединений вертикально интегрированных энергокомпаний с централизованным планированием и контролем режимов всех генерирующих и передающих мощностей - закончилось в 1990-е годы. Бурное развитие газотурбинных технологий наряду с увеличением добычи природного газа, появление распределенной генерации (в том числе - на основе возобновляемых источников энергии), внедрение управляемого энергопотребления - «умных» сетей (smart grid) стимулировали переход к конкурентной электроэнергетике . $^{8}$

Принятый в США в 1992 г. Закон об энергетической политике разрешил деятельность независимых производителей электроэнергии. Рыночное ценообразование на оптовом рынке в течение одного десятилетия вытеснило ценообразование

\footnotetext{
${ }^{8}$ Рынок электроэнергии - рынок несовершенной конкуренции, ибо спрос на нее не зависит от текущей ценовой ситуации на рынке, а цена зависит только от коллективного производства электроэнергии на множестве электростанций, различающихся по технологии, мощности и затратам. В такой научной дисциплине, как «общая энергетика», допускается существование 36 видов «энергетических рыночных товаров», имеющих совершенно различную структуру затрат, в том числе 15 видов тепловой и электрической энергии и 21 вида энергетической мощности. Различие этих затрат по стоимости может достигать 20-35 раз и может быть предоставлено на рынке в виде ценообразования на основе анализа маржинальных издержек.
}

на основе регулируемых государством тарифов, привязанных к себестоимости производства и передачи электроэнергии.

Затем в США были отменены ограничения на доступ независимых генерирующих компаний к сетевой инфраструктуре. Плата за передачу электроэнергии перестала зависеть от расстояния между точками ее продажи и покупки (принцип «почтовой марки»). Магистральные сети либо остались в собственности генерирующих компаний, либо перешли в управление независимых сетевых организаций, часть которых получила лицензии на осуществление диспетчерского управления.

Реформа способствовала сглаживанию разницы в ценах на электроэнергию в различных штатах, хотя не обошлось без казусов. Например, в Калифорнии, где основной объем электроэнергии вырабатывается на ГЭС, цены на электроэнергию выросли втрое, а в 2001 г. из-за засушливого лета и обмеления водоемов объемы производства упали настолько, что это привело к веерным отключениям и продаже крупнейшей вертикально интегрированной компанией San Diego Gas and Electric своих генерирующих активов. Энергетический кризис оказался настолько серьезным, что потребовалось прямое вмешательство президента США, который директивно указал властям других штатов продавать электроэнергию Калифорнии по регулируемым ценам [Давыдовский, 2011].

В 2003 г. Евросоюз принял Директиву по дерегулированию и либерализации электроэнергетики. Целью реформы провозглашались снижение цен на электроэнергию, улучшение качества обслуживания и рост конкуренции.

Реформа предусматривала разделение вертикально интегрированных энергокомпаний по видам деятельности и обеспечение конкуренции в секторах генерации и сбыта электроэнергии. При этом речь шла лишь о юридическом разделении, которое не предполагало обязательной смены владельца при условии, что операторы передающих и распределительных сетей обеспечивают недискриминационный доступ к сети с экономически обоснованной ценой подключения.

Директива нацеливалась на создание совместимых условий поставки электроэнергии потребителям в странах - членах ЕС, 
что позволило бы в дальнейшем прийти к единому европейскому рынку электроэнергиия.

К 2008 г. на территории ЕС развернули деятельность девять основных бирж электроэнергии: NordPool, EEX, IPEX, Powernext, APX NL, APX UK, Belpex, Endex и Omel. Предметом биржевой торговли являются стандартизированные лоты по $10 \mathrm{MBT} \cdot$ ч электроэнергии в определенный получасовой период следующего дня. Такая форма торговли дает генерирующим и энергоснабжающим компаниям возможность гибко подстраиваться к текущей ситуации, прикупая недостающие объемы электроэнергии либо оперативно продавая возникшие излишки.

Кроме того, в биржевой торговле могут принимать участие трейдерские компании, ведущие спекулятивные или хеджевые операции. Торговля контрактами, а не реальной электроэнергией, придает рынку дополнительную ликвидность и снижает роль отдельных крупных поставщиков и покупателей.

Наиболее развитым рынком считается рынок Северной Европы, в особенности его скандинавская часть, где на бирже NordPool организованы торги «на сутки вперед» и балансирующий рынок. На этом рынке наблюдаются одни из самых низких цен в Европе, а ликвидность превышает 30\%. Развитость электросетей позволяет без значительных потерь обеспечить перетоки электроэнергии от производителя к потребителям, находящимся в самых удаленных точках региона.

Мировой опыт создания конкурентных рынков подтвердил возможность трех основных механизмов ценообразования.

1. Текущий рынок электроэнергии, где торговля происходит в режиме реального времени. Это - спотовый, «балансирующий», или рынок «на сутки вперед». Его участники покупают объемы электроэнергии, которые они не смогли заранее спланировать

${ }^{9} \mathrm{~B}$ «Рамочной стратегии Энергетического союза с долгосрочной политикой изменения климата» (принята в 2015 г.) сформулированы следующие основополагающие принципы деятельности ЕврЭС: декарбонизация экономики; энергоэффективность как способ снижения энергопотребления; единый энергетический рынок; энергобезопасность, солидарность и доверие; исследования, инновации и конкурентоспособность. В марте 2016 г. 16 системных операторов Евросоюза создали региональный Центр по расчету пропускной способности. Разрабатывается общая методология координированного перераспределения трансграничных перетоков электроэнергии и организации встречной торговли, в целях ликвидации перегрузок в объединенной передающей сети. в рамках прямых договоров между потребителями и производителями электроэнергии.

Производители электроэнергии выходят на рынок со своими мгновенными (или часовыми) характеристиками издержек (предложения), которые представляют собой зависимости предельных (приростных) издержек (на 1 кВт·ч) от отпускаемой мощности (часовой выработки электроэнергии) генерирующих компаний.

Равновесная цена электроэнергии на текущем рынке в тот или иной момент времени (час суток) устанавливается по соотношению этих кривых со спросом потребителей в этот момент (час).

Суточная средняя рыночная цена демонстрирует естественный утренний максимум, дневной полупик, вечерний пик и ночной «провал».

Месячная цена учитывает снижение потребления электроэнергии предприятиями в выходные дни и повышение в рабочие.

2. Краткосрочный (годовой) рынок электроэнергии, имеющий форму двусторонних контрактов производителей и потребителей (или сбытовых компаний), заключаемых на 1-3 года (форвардные или фьючерсные рынки).

Краткосрочный рынок определяет основные результаты экономической деятельности производителей (годовые издержки, доходы и прибыль) и расходы потребителей на покупку электроэнергии. На этот рынок производители выходят со своими краткосрочными издержками (средними и предельными), представляющими зависимость издержек на единицу продукции от годового ее производства.

Равновесная цена устанавливается по соотношению предельных издержек (являющихся одновременно кривыми предложения) производителей и спроса покупателей. Прибыль (или убыток) производителя определяется как разность между равновесной ценой и средними издержками.

Годовая цена учитывает сезонные (весенне-летние и осеннезимние) колебания потребления электроэнергии.

3. Долгосрочный рынок электроэнергии, охватывающий долгосрочный период и предполагающий возможности расширения производства (мощности производителей не фиксируются). Производители выступают со своими долгосрочными издержками (средними и предельными) и кривыми предложения, а потребители (покупатели) - с долгосрочными кривыми спроса. 
На долгосрочном рынке реализуются интересы так называемого базового потребления (по объемам) и предсказуемости (по цене). Это позволяет снизить волатильность цен для конечных потребителей и обеспечить стабильность поставок. Долгосрочное равновесие (и цена) на таком рынке определяется на пересечении долгосрочных кривых спроса и предложения. Долгосрочный рынок подает ценовые сигналы, стимулирующие строительство новых электростанций и электросетей со сроком окупаемости 10-15 лет.

Предполагается, что благодаря рынку электроэнергии наибольшую загрузку должны получать те генерирующие компании, которые производят электроэнергию с наименьшими издержками, но это лишь в теории. На практике основной компонент издержек - топливная составляющая - определяется не правилами торговли, а технологией, амортизацией и ценами на топливо. Для ГЭС величина зависимости издержек от погодных условий в рамках годового цикла еще больше снижает значимость рыночных правил.

Ветровая и солнечная энергетика вообще не имеют расходов на топливо. С учетом субсидий, которые в странах ЕС получают производители «чистой» электроэнергии, такие компании могут в определенные дни устанавливать тариф ниже нуля евро за 1 кВт·ч, и при этом получать прибыль.

Впрочем, условия оптовой торговли для ветровых и солнечных электростанций по общему правилу определяются среднемесячными показателями использования мощностей, значения которых зависят от изменений интенсивности солнечного излучения и силы ветра на разных территориях и в разные периоды года.

За последние пять лет стоимость «чистой энергии» падала в среднем на $10 \%$ в год. Если этот тренд сохранится, то уже в ближайшие годы цены на нее будут существенно ниже, чем электроэнергии, получаемой при сжигании любого вида топлива. В этой связи эксперты прогнозируют появление на энергетических рынках нового класса игроков - аккумулирующие электростанции (либо, по меньшей мере, увеличение роли аккумуляции там, где она уже используется).

Аккумуляция в технологическом смысле поможет решить многие проблемы, порождаемые парадоксом отрицательной цены. Она усреднит цену и сгладит колебания мощностей - с выгодой и для классических, и для «чистых» производителей, и для потребителей.

\section{Становление рыночных отношений в российской электроэнергетике}

В России после одобрения правительством в 2000 г. «Основных положений Энергетической стратегии РФ на период до 2020 года» ключевыми мерами реформирования электроэнергетической отрасли были следующие:

- разделение активов электроэнергетического комплекса по видам деятельности (монопольные и потенциально конкурентные),

- приватизация активов в потенциально конкурентных видах деятельности,

- формирование рыночной конкурентной среды.

До реформы (1992-2008 гг.) государство отвечало за тарифы (ФЭК России) и регулировало вопросы технического контроля (Энергонадзор). Весь остальной функционал возлагался на РАО «ЕЭС России», которое фактически являлось отраслевым квазиминистерством, владевшим 72\% установленной мощности всех электростанций России и 96\% протяженности всех линий электропередачи.

В 1998 г. уровень оплаты электроэнергии и тепла потребителями не дотягивал до 85\%, причем на долю «живых» денег приходилось менее 20\%, остальное составляли векселя, зачеты, бартер. Двадцать энергосистем и федеральных электростанций находились на разных стадиях процедуры банкротства с реальной перспективой быть распроданными за долги и ликвидированными. К концу 1999 г. доля «живых» денег в платежах за энергию выросла до 49\%, в конце 2000 г. - до 100\%. С января 2001 г. в РАО «ЕЭС» расчеты в неденежной форме были официально запрещены и полностью исключены.

Одним из главных мотивов реформы российской электроэнергетики был так называемый «крест Чубайса» - гипотетическая ситуация, когда спрос на электроэнергию превысит предложение, а износ советских электростанций и электросетей не позволит нарастить производство.

Реформаторы утверждали, что либерализация и продажа генерирующих мощностей позволят привлечь новых инвесторов, 
которые введут новые мощности за свой счет. На продаже акций генерирующих компаний государство заработало 900 млрд руб. При этом покупателей обязали подписать инвестиционные обязательства по строительству новых мощностей (так называемые ДПМ) с тем, чтобы ввести в строй 30 ГВт мощности с 2007 г. по 2017 г. [Гайдар, Чубайс, 2008].

С 2003 г. по 1 апреля 2006 г. региональные АО-энерго были поделены по видам бизнеса, т.е. в каждом субъекте РФ появились самостоятельные генерирующие, сетевые и сбытовые компании. Сформировалась более прозрачная и понятная инвесторам структура энергетической отрасли.

К концу 2007 г. капитализация РАО «ЕЭС России» составляла почти 50 млрд долл. (против 12 млрд долл. в 1998 г.). В последние годы существования холдинга его бумаги были наиболее популярными «голубыми фишками» России.

С ликвидацией в 2008 г. РАО «ЕЭС России» управление электроэнергетикой в Российской Федерации стало осуществляться по принципу оптимального сочетания централизации и децентрализаци.

Законодательно устанавливалось ограничение на совмещение деятельности по передаче электрической энергии с деятельностью по ее производству и купле-продаже, т.е. на совмещение естественно-монопольных и конкурентных видов деятельности.

Управление технологической инфраструктурой было разделено между четырьмя группами компаний.

1. ПАО Системный оператор (СО) ЕЭС - организация, осуществляющая диспетчерское управление и являющаяся собственностью государства (100\% акций). Главная ее функция - соблюдение технологических параметров функционирования энергосистемы для работающего и резервного состава мощностей (и графика их нагрузки).

СО ЕЭС отдает распоряжения генерирующим и сетевым компаниям об отключении потребителей в условиях предельных режимов производства электроэнергии, контролирует очередность вывода в ремонт генерирующих и сетевых мощностей и исполнение инвестиционных программ, проводит конкурентный отбор мощности (КОМ) и обеспечивает функционирование балансирующего рынка ${ }^{10}$.

2. Федеральная сетевая компания (ПАО «ФСК ЕЭС») - организация, осуществляющая управление магистральными линиями электропередачи напряжением 220-500-750 кB (75\% акций принадлежит государству).

${ }^{10}$ По состоянию на 31.12 .2008 в структуре ОАО «СО ЕЭС» находилось 7 объединенных диспетчерских управлений (ОДУ), 57 региональных диспетчерских управлений (РДУ) и 7 региональных предприятий «Энерготехнадзор».
ФСК занимается управлением, эксплуатацией и развитием Единой национальной электрической сети (ЕНЭС) и предоставляет участникам оптового рынка услуги по передаче электроэнергии.

3. ПАО «Россети» - организация, осуществляющая корпоративное управление Межрегиональными распределительными сетевыми компаниями (МРСК). Контролирующим акционером является государство в лице Федерального агентства по управлению государственным имуществом, владеющее $87,9 \%$ долей в уставном капитале ${ }^{11}$.

4. Оптовые (ОГК) и территориальные (ТГК) генерирующие компании, выполняющие функции эксплуатирующих организаций (операторов) тепловых и гидроэлектрических станций. Их первоначальная структура была утверждена правительством РФ в сентябре 2003 г. Тогда на рынке присутствовали 10 ОГК и 14 ТГК.

Все ОГК и ТГК с участием частного капитала связаны с государством договорными обязательствами на поставку мощности (ДПМ) и имеют государственные гарантии на возмещение в течение десяти лет стоимости инвестиций в развитие генерации ${ }^{12}$.

К организациям коммерческой инфраструктуры относятся:

- ПАО «Администратор торговой системы» (АО «АТС»); Наряду с системным оператором управляет загрузкой электростанций страны, но делает это не технологическими или административными, а финансовыми методами;

- ПАО «Центр финансовых расчетов» (АО «ЦФР»);

- Ассоциация «НП Совет рынка». Ее задача - обеспечение баланса интересов между участниками рынка и единство функционирования оптового и розничного рынков электроэнергии.

Оптовый рынок электроэнергии устроен следующим образом: ОГК и ТГК выставляют свои предложения объемов производства и цены, покупатели заявляют свое потребление, а некоторые и максимальную цену, которую готовы заплатить. Порог для входа генерирующей компании на оптовый рынок - установленная мощность, равная или превышающая 25 МВт.

Далее ПАО «АТС» проводит централизованный отбор ценовых заявок поставщиков.

Регулируемые договоры основываются на принципе take or рау, то есть обязательной поставки и покупки.

От всего объема оптового рынка $80 \%$ составляет «спот»рынок «на сутки вперед».

${ }^{11}$ Имущественный комплекс ПАО «Россети» включает в себя 36 дочерних и зависимых общества, в том числе 14 межрегиональных и магистральную сетевую компанию. Компания управляет 2,3 млн км линий электропередачи, 496 тыс. подстанциями трансформаторной мощностью более 773 тыс. МВА.

${ }^{12}$ По состоянию на 31 декабря 2008 г. в суммарной установленной мощности электростанций России доля вошедших в состав ОГК и ТГК составила около $60 \%$ (134,2 млн кВт), в том числе ОГК $-35 \%$ ( 78,3 млн кВТ), ТГК $-25 \%$ ( 55,9 млн кВт). 
Модель торговли электроэнергией на российском оптовом рынке по своим характеристикам больше напоминает обязательный централизованный пул, в котором продажа электроэнергии происходит через одну унифицированную сторону, и покупатель не видит продавца (в отличие от биржи, где покупатель выбирает продавца $)^{13}$.

Динамика оптовых цен стала подавать поставщикам и потребителям рациональные сигналы об эффективности загрузки генерирующих мощностей и оптимизации режима потребления при краткосрочных, среднесрочных и долгосрочных горизонтах планирования. Однако реформа отрасли далека от завершения, а единая энергосистема России на самом деле таковой не является из-за ряда ограничений.

Изначально российский оптовый энергетический рынок был разделен на две ценовые зоны: европейскую часть (с Уралом) и Сибирь. Обе они состоят из сегментов «свободного перетока электрической энергии (мощности)», разделяющих ценовую зону на неравнозначные части, внутри которых могут передаваться большие мощности, но вывести их за пределы зоны не позволяет пропускная способность магистральных электросетей. Она же создает так называемые «запертые» генерирующие мощности.

На сегодняшний день количество сегментов «свободного перетока электрической энергии (мощности)» равно 21, и каждый из них уникален с точки зрения структуры и состава генерирующих мощностей, протяженности магистральных ЛЭП и распределительных сетей, характера электрических нагрузок и т.д.

Архангельская и Калининградская области, Республика Коми и регионы Дальнего Востока относятся к неценовым зонам. Система ценообразования здесь осталась такая же, как и до реформы РАО «ЕЭС России»: все станции получают регулируемые тарифы на электроэнергию и мощность.

Конкуренция на розничных рынках, которая декларировалась как краеугольный камень реформы российской электроэнергетики, начала обретать черты соперничества в основном за статус гарантирующего поставщика (ГП).

Последний, выполняя сбытовую функцию, организует перепродажу электроэнергии, купленной на оптовом рынке, розничным

${ }^{13}$ Подробнее см.: [Редькин, 2013]. потребителям. При этом ГП принимает на себя все обязанности как сетевых, так и генерирующих компаний, не обладая ни сетевым, ни генерирующим оборудованием. Соответственно, ГП может обеспечивать технологические гарантии, только требуя их исполнения со стороны сетевых и генерирующих компаний.

Сейчас в России насчитывается около 300 гарантирующих поставщиков, а объем розничного рынка электроэнергии составляет около 2 трлн руб.

Значительное количество «розничных» потребителей электроэнергии не имеют возможности выбирать энергосбытовую компанию ввиду отсутствия альтернативного поставщика.

Снижения или хотя бы стабилизации цен на электроэнергию на дореформенном уровне не произошло. Напротив, цены на электроэнергию для населения в среднем поднялись почти в 3,8 раза, а для промышленных потребителей-в 2,7 раза. В более или менее благополучном 2012 г. цена электричества в России для средних промышленных потребителей составила в эквиваленте около 0,122 евро/кВт·ч - это существенно выше, чем в «старых» странах ЕС (15 государств), Северной Европе и в США.

Если сравнивать с США, наши цены выше в 2,5 раза, с Германией - на 41\%, со средней ценой в ЕС (27 государств) - на $25 \%$. Только в новых странах ЕС, а также в Италии и Турции электричество пока еще дороже, чем в России.

Тариф на электроэнергию можно представить в виде «пирога» из четырёх слоёв. Первый - 50-55\% - это стоимость энергии и мощности на оптовом рынке, т.е. ее закупочная цена. Второй $-40-45 \%$ - стоимость услуг по передаче электроэнергии, за которые сбытовая компания платит сетевой. Третий - всего $1 \%$ - плата за инфраструктуру рынка. Таким образом, до $98 \%$ тарифа уходит на оплату различных услуг и непосредственно товара - электроэнергии и мощности. Последний слой - 2-3\% - так называемая сбытовая надбавка, - это то, на что «живёт» гарантирующий поставщик. Ее размер устанавливается государством.

Наибольшая доля роста цен на электроэнергию приходится на топливную составляющую. В 2015 г., по данным «Газпрома», средняя оптовая цена газа для внутреннего рынка с учетом НДС составила 4300 руб. за тысячу кубов против 1330 руб. в 2006 г. В структуре издержек генерирующих компаний, работающих на природном газе, расходы на топливо выросли до 60-85\%. 
Между тем на природном газе в России вырабатывается примерно $50 \%$ электричества.

Существенно ухудшился показатель расхода электроэнергии на ее транспорт (сетевые потери) - с 8,7\% в 1990 г. до 11,2\% к 2013 г.

Удельная стоимость передачи киловатт-часа по магистральным сетям за тот же период увеличилась в сравнимых ценах с 5 до 33 коп.

Притчей во языцех стала «последняя миля»- нерыночная схема, при которой крупные потребители, подключенные к магистральным сетям ФСК, оплачивали не только ее тариф, но и тарифы распределительных сетей, услугами которых не пользовались. Для этого распределительные сетевые компании брали в аренду у ФСК ЕЭС «последнюю милю» - участок сетей, к которым подключен потребитель. Данный механизм повышал цену электроэнергии для крупных предприятий, но позволял понижать тарифы для остальных и закончил свое действие 1 января 2014 г. с установлением запрета на «прямое подключение потребителей» к магистральным сетям ФСК. Потребители на высоком напряжении (предприятия металлургии и химической промышленности) получили тарифную скидку (компенсацию) в размере 20-30\%.

Ни один из участников цепочки поставщиков электроэнергии не несет материальной ответственности перед конечным потребителем. Фактически потребители вынуждены оплачивать все инструменты надежности, но гарантий надежности им никто не дает и ущерб от прерывания электроснабжения не возмещает.

Рост тарифов, относительная недоступность сетевой инфраструктуры, перекосы в ценовом регулировании в отношении технологического присоединения и услуг по передаче электрической энергии, нарушение качества услуг в сфере электроснабжения вызывают законное недовольство российских предпринимателей, побуждают их к поиску альтернативных вариантов электроснабжения ${ }^{14}$.

${ }^{14}$ По сообщениям СМИ, стоимость одного присоединенного кВт в С.-Петербурге достигает 30-70 тыс. руб. Для открытия своего кафе или магазинчика необходимо 30-50 кВт; это значит, необходимо заплатить 1,5-3,5 млн руб. Для открытия малого предприятия в промышленности требуется 100-300 кВт, это потребует затрат в 3-21 млн руб. Это потери бизнеса без затрат на проектирование и выполнение технических условий; последнее стоит не меньше, чем сама энергетика.
С появлением на рынке энергетического оборудования сравнительно недорогих газопоршневых и газотурбинных установок единичной мощности от 2,5 до 450 МВт крупные промышленные потребители все более охотно переходят на автономное энергообеспечение. Тут срабатывает вполне обоснованная логика: зачем платить за юридические гарантии в составе платы за электроэнергию, если они все равно не обеспечиваются; гораздо проще обзавестись собственной генерацией, а потенциальные убытки компенсировать за счет более дешевой электроэнергии.

$$
* * *
$$

Исследование показало, что электроэнергия и услуги по ее предоставлению имеют двойственную экономическую природу. В зависимости от того, рассматривается электроэнергия как вещь или как общественное материальное благо, возможны различные базовые модели построения системы электроснабжения в масштабе национальной и даже мировой экономики.

Русские большевики не случайно выбрали электроэнергетику «основным звеном» социалистического преобразования общества, резонно полагая, что каждая вновь построенная крупная государственная электростанция и примыкающая к ней распределительная сеть - это и есть искомая техническая основа для объединения товаропроизводителей в крупные территориально-отраслевые производственные комплексы, управляемые по единому плану.

Однако мы видим, что тенденции «социализации» (с разной степенью приближения к идеалу «единого электрохозяйства») в 1920-1930-е годы проявились и в электроэнергетике развитых капиталистических стран, когда в результате прогресса энергетической техники и конкурентной борьбы энергетических компаний электроснабжение стало разновидностью «естественной монополии». Больше всех в обобществлении электроэнергетики и отрицании товарного характера производства электроэнергии и предоставлении энергетических услуг преуспела нацистская Германия.

Нелишне отметить, что современная доктрина энергетического права, рассматривающая электроэнергетику как совокупность конкурентных рынков, смогла, что называется, «овладеть сознанием масс» лишь после полного отказа правящих элит от марксистских 
и кейнсианских идей макроэкономического регулирования. Ни одна из 100 стран, которые в 1990-е годы приступили к либерализации экономических отношений в области электроэнергетики, не намерена возвращаться к дореформенному состоянию.

Но неоднозначность последствий либерализации электроэнергетики, являющейся базовой отраслью индустриального общества, увеличивает количество противников реформы в России и вызывает разочарование даже среди убежденных «рыночников» и либералов.

Полагаю, что как бы ни были велики шансы на победу сторонников контрреформ, следует не упускать из виду новейшие научно-технические разработки в области возобновляемых источников энергии, распределенной генерации и создания «интеллектуальных электросетей». Не исключено, что данные технологии если и не изменят качественно нынешнюю доктрину энергетического права, то хотя бы внесут в нее общественнозначимые коррективы.

Для российской электроэнергетики на современном этапе реформирования особое значение приобретает внедрение инновационного силового оборудования системообразующих электрических сетей, необходимое для повышения пропускной способности электрической связи между энергетическими узлами. Это не только уменьшит сетевые потери, но и будет способствовать объединению сегментов ценовых зон и повышению уровня конкуренции между генерирующими компаниями.

В части генерации как никогда актуально замещение неэффективного оборудования новым с меньшей мощностью, но резким увеличением КПД, что обеспечит, с одной стороны, повышение надежности энергосистем, с другой - позволит снизить затраты на поддержание резервной мощности, давящие на цены оптового рынка электроэнергии.

\section{Литература}

Гайдар Е., Чубайс А. Экономические записки. М.: Российская политическая энциклопедия (РОССПЭН), 2008.

Гартман О. Г. Пар высокого давления/ Пер. с нем. Б. А. Люблинского; под ред. Д. А. Доллежаль. М.: Государственное техническое изд., 1927.

Давыдовский Ф.Н. Либерализация мировой электроэнергетики и проблемы становления конкурентных рынков в условиях реструктуризации//Экономика, предпринимательство и право. 2011. № 7.
Канщер Ю.А. История развития энергоснабжения в России и науки, его изучающей// Энергетика и право. 2013. № 2.

Кукель-Краевский С. Мировой инженерный конгресс и мировая энергетическая конференция 1929 г.// Плановое хозяйство. 1930. № 3. С. 227-248.

Лахно П.Г. Энергетическое право России: понятие и сущность. Российская модель энергетического права//Библиотека научных публикаций Электронного периодического справочника «Система ГАРАНТ». 2013. № 1. С. 3.

Милль Дж. Ст. Основы политической экономии Т. 1. М.: Прогресс, 1980 C. 302 .

Михайлов В.И. Электрификация Франции// Электричество.1936. № 17.

Попондопуло В.Ф. Энергетическое право и энергетическое законодательство: общая характеристика, тенденции развития. Энергетика и право. М.: Изд. «Юрист», 2008

Редькин И.В. Анализ ключевых проблем государственного регулирования электроэнергетики по результатам завершения переходного периода реформы // Энергетическое право. 2013. № 1.

Розин Н.Н. О похищении электрической энергии // Вестник права. 1899 № 10 .

Фомичева И.В. Эволюция естественной монополии, как рыночной структуры //Теоретическая экономика. 2013. № 1. С. 50.

Яковлев В.Ф., Лахно П.Г. Энергетическое право как комплексная отрасль права России. Энергетическое право России и Германии: сравнительно-правовое исследование / Под ред. П. Г. Лахно. М.: Изд. «Юрист», 2011.

Leonard S. Hyman, America's electric utilities: past, present and future.- Public Utilities Reports, Inc. Arlington. Virginia. 1988.

Ramsey F. A Contribution to the Theory of Taxation // Econ. Journ. 1927. Vol. 37. № 1 .

Статья поступила 02.06.2017

\section{Summary}

Simonov N.S., Federal Grid Company (JSC «FGC UES»), Moscow

Reforms in the Electric Power Industry of Russia in the Context of Energy Law Development

The subject of research is the Genesis of the doctrine of electric power supply as one of the sources of energy law. It is proved that the attitude of society to a proprietary form of electricity and energy services is determined by specific historical conditions, and mainly technology generation and transmission of electricity. In the vast historical material with the use of a comparative analysis traces the process of the civil law understanding of the legal regime of electricity supply in the industrial development countries, Russian Empire, USSR and modern Russia. It is concluded that modern technologies, more than ever, contribute to the liberalization of the electric power industry and the creation of a market competition between electricity suppliers.

Electric power industry; power supply; power law; the great public utilities; electric power market 


\section{References}

Gajdar E., Chubajs A. (2008). Jekonomicheskie zapiski. M. ROSSPJeN Publ. (In Russ).

Gartman O.G. (1927). Par vysokogo davlenija. Per. s nemeckogo B. A. Ljublinskogo: pod red. D. A. Dollezhal'. M.: Gosudarstvennoe tehnicheskoe izdatel'stvo. (In Russ).

Davydovskij F.N. (2011). Liberalizacija mirovoj jelektrojenergetiki i problemy stanovlenija konkurentnyh rynkov v uslovijah restrukturizacii. Jekonomika, predprinimatel'stvo i pravo. [Journal of Economics, Entrepreneur ship and Law] No. 7. (In Russ).

Kancer Ju.A. (2013). Istorija razvitija jenergosnabzhenija v Rossii i nauki, ego izuchajushhej. Jenergetika i pravo. No. 2. (In Russ).

Kukel'Kraevskij S. (1930). Mirovoj inzhenernyj kongress i mirovaja jenergeticheskaja konferencija 1929 g. Planovoe hozjajstvo. No. 3. Pp. 227-248. (In Russ).

Lahno P.G. (2013). Jenergeticheskoe pravo Rossii: ponjatie i sushhnost'. Rossijskaja model' jenergeticheskogo prava. Biblioteka nauchnyh publikacij Jelektronnogo periodicheskogo spravochnika «Sistema GARANT». No. 1. P. 3. (In Russ).

Mill' Dzh. St. (1980). Osnovy politicheskoj jekonomii T. 1. Moscow: Progress Publ. P. 302. (In Russ).

Mihajlov V.I. (1936). Jelektrifikacija Francii. Jelektrichestvo. No. 17. (In Russ).

Popondopulo V.F. (2008). Jenergeticheskoe pravo i jenergeticheskoe zakonodatel'stvo: obshhaja harakteristika, tendencii razvitija. Jenergetika i pravo. Moscow: Jurist Publ. (In Russ).

Red'kin I.V. (2013). Analiz kljuchevyh problem gosudarstvennogo regulirovanija jelektrojenergetiki po rezul'tatam zavershenija perehodnogo perioda reform. Jenergeticheskoe pravo. No. 1. (In Russ).

Rozin N.N. (1899). O pohishhenii jelektricheskoj jenergii. Vestnik prava. No. 10. (In Russ).

Fomicheva I.V. (2013). Jevoljucija estestvennoj monopolii, kak rynochnoj struktury. Teoreticheskaja jekonomika. No. 1. P. 50. (In Russ).

Jakovlev V.F., Lahno P.G. (2011). Jenergeticheskoe pravo kak kompleksnaja otrasl' prava Rossii. Jenergeticheskoe pravo Rossii i Germanii: sravnitel'nopravovoe issledovanie. Pod red. P. G. Lahno. Moscow: Jurist Publ. (In Russ).

Leonard S. (1988). Hyman, America's electric utilities: past, present and future.Public Utilities Reports, Inc. Arlington. Virginia.

Ramsey F.A (1927). Contribution to the Theory of Taxation. Econ. Journ. Vol. 37. No. 1. 